\title{
Teaching and Learning with Technology: Ramification of ICT Integration in Mathematics Education
}

\author{
${ }^{1}$ Marvelino M. Niem, ${ }^{2}$ Rizza U. Veriña, \& ${ }^{3}$ Emil C. Alcantara \\ ${ }^{1}$ marvelino.niem@deped.gov.ph \\ ${ }^{3}$ Batangas State University - Main Campus \\ ${ }^{3}$ Batangas City, Philippines
}

\begin{abstract}
The study was undertaken to determine the extent of integration of Information and Communication Technology (ICT) to mathematics teaching and learning processes among junior and senior high school Mathematics teachers in the Division of Tanauan City. Further, the research also identified challenges encountered in ICT-based teaching and learning mathematics. This study employed mixed method of research, survey questionnaire, interview, and focus group discussion (FGD) with the 77 teachers. The respondents were determined using Raosoft at five percent margin of error and used stratified random sampling. The frequency, percentage, mean, standard deviation, and Ttest were the statistical tools used to analyse the data. Based on the findings, majority of the respondents were female, bachelor's graduate, from teachers I to III, 15 years below in the service and not active in attending ICT-related seminars. Most of them use technology in writing lesson plans, in computing students' results and, in teaching the lesson through power point presentations. However, due to the lack of resources and little fund from the Maintenance and Other Operating Expenses (MOOE), the respondents rarely use telecommunication devices such as cable, satellite, fax-machine, etc. to interact with students. There is a significant difference between the extent of the use of ICT in teaching and learning mathematics and years in teaching. Lack of ICT facilities and trainings attended and confidence in the use of ICT were the commonly identified challenges. With the aforementioned, the researchers recommended that mathematics teachers must be given more opportunities to participate ICT-based seminars and trainings.
\end{abstract}

Keywords: Mathematics education, ICT-based teaching and learning, junior and senior high school mathematics teachers, qualitative and quantitative, Philippines

\section{Introduction}

Technologies as link to new knowledge, resources and high order thinking skills have entered classrooms and schools worldwide. Personal computers, CD-ROMS, on line services, the World Wide Web and other innovative technologies have enriched curricula and have altered the types of teaching available in the mathematics classroom. Schools' access to technology is increasing steadily every day and most of these newer technologies are now even used in traditional classrooms. The rapid development of Information and Communication Technology (ICT) brings a new paradigm in education in various aspects especially in mathematics teaching and learning, among others are the change from traditional learning to new learning, information delivery to information exchange and teacher-centred to student-centred. Integration of ICT into teaching and learning is not a 
method but a medium in which a variety of methods, approaches and pedagogical philosophies may be implemented (Salehi \& Salehi, 2012).

Ngeze (2017) pointed out that the use of ICT in teaching and learning has brought new teaching and learning experience to both teachers and students in many countries. ICT integration brings significant change in education acceleration and innovation in various countries, generally those related to the learning process, particularly in mathematics education. ICT integration in mathematics education offers mathematics teachers with integrative teaching methods that motivate students' learning, support their independent learning and active participation in the discovery of mathematics concepts and topics that helps them have deeper understanding of the mathematical ideas (Baya'a \& Daher, 2013). Also, it is stressed by the National Council of Teachers of Mathematics (NCTM) that, in mathematics teaching and learning process, technology is necessary and must be adapted (NCTM, 2000).

Integrating ICT into teaching and learning has become a great concern for many educators in developing countries like the Philippines. Integration of ICT in the Philippines plays a vital role in the educational system. The Philippine government have recognized the pressing concern in improving the quality education to be able to participate in a dynamic global economy. Among the critical governmental efforts are: the priority budget for education, Basic Education Reform Agenda (BESRA), medium term development program for 2011-2016, curriculum reform (e.g., K-12), and the ICT for education (ICT4E) (Manaligod \& Garcia, 2012).

However, there are some arguments that the use of technology cannot replace conceptual understanding, computational fluency, or problem-solving skills. In a balanced mathematics programme, the strategic use of technology enhances mathematics teaching and learning. Teachers need to be knowledgeable decision makers in determining when and how their students can use technology most effectively. Schools and mathematics programmes have to provide students and teachers with access to instructional technology, including appropriate calculators, computers with mathematical software, internet connectivity, handheld data-collection devices, and sensing probes. Curricula and courses of study have to incorporate instructional technology in learning outcomes, lesson plans, and assessments of students' progress.

In the study of Mishra and Koehler (2006) TPACK framework, which focuses on technological knowledge (TK), pedagogical knowledge (PK), and content knowledge (CK), offers a productive approach to many of the dilemmas that teachers face in implementing educational technology in their classrooms. The point of this theory is to understand how to use technology to teach concepts in a way that enhances students learning experiences. Thus, teachers may utilize technology properly in classroom to help students develop deeper understanding of mathematics concepts.

ICT on the teaching and learning mathematics cannot be denied by every mathematics teacher and educator. Some studies show that the use of ICT in teaching and learning mathematics has a positive impact on students' performance and learning achievement (Delen, \& Bulut, 2011; Comi, Argentin, Gui, Origo, \& Pagani, 2017; Eickelmann, Gerick, \& Koop, 2017). The role of ICT in the curriculum is much more than simply a passing trend. It provides a real opportunity for teachers of all phases and subjects to rethink fundamental 
pedagogical issues alongside the approaches to learning that students need to apply in classrooms. Transferring of information, collecting of data and researching are the multiple benefits that students can get from ICT, but it still a dream for many. Most public schools in the Philippines have no complete ICT facilities like insufficient number of computer units, the unstable internet connection, and the lack of teachers' skills and knowledge on the proper use of technology which results in poor student and school performance. This was evidently seen in the 2003 Trends in International Mathematics and Science Study (TIMMS), the Philippines is among the worst performer among participating countries. The country scored way below the average international score. It ranked $23^{\text {rd }}$ among 25 in the elementary level and $34^{\text {th }}$ in 38 countries in the secondary level for the mathematics examination. TIMSS 2008 advanced results showed that in general, Philippines performed least among ten (10) participating countries in mathematics. These observations are collaborated by World Economic Forum's Global Competitiveness Report of 2010-2011, that finds the country ranking low in the quality of science and mathematics, i.e., $112^{\text {th }}$ among 139 countries surveyed (Swab, 2011 cited in Manaligod \& Garcia, 2012).

Due to ICT's importance in mathematics education, the researchers felt the need to study the following: (1) to determine the profile variables of the Mathematics teachers in terms of: sex, highest educational attainment, years in teaching, designation and seminars attended about ICT integration; (2) to what extent do the teachers integrate ICT in teaching and learning mathematics; (3) to identify if there are significant differences between the teachers' integration of ICT-based teaching and learning in mathematics when grouped according to profile variables; and (4) to recognize the challenges encountered by the teachers in ICT-based teaching and learning mathematics.

\section{Methodology}

This study utilized mixed methods of research. In the qualitative part, the researchers used interview methods and FGD. However, in the quantitative part, descriptive methods were used to report the extent of the teacher integration of ICT and the challenges faced by the teachers in integrating ICT into teaching and learning mathematics. There were 95 public school mathematics teachers both in junior and senior high schools in 16 secondary schools in the Division of Tanauan City which is owned by the government wherein the students were also from the city itself. It is a highly urbanized city located at the southern part of Metro Manila in the province of Batangas which is an hour drive from it. Using Raosoft sample size determination, from 95 the researchers got 77 as the sample and the respondents were selected using a stratified random sampling technique per school.

The researchers initially secured the permit to conduct a study from the Schools Division Superintendent. Before handling the questionnaires, the researchers used a researcher-made questionnaire that was validated by two mathematics professors from Batangas State University-Main Campus and two external validators, one was a Master Teacher in Mathematics and the other one was an Education Program Supervisor in Mathematics by checking its content mathematically. After checking the validity, it was made ready for dry-run to 20 secondary school mathematics teachers from the Division of Lipa City. Then, the reliability of the instrument was obtained using Cronbach alpha statistical tool 
and reliability co-efficient was 0.737 . The research instrument was deemed valid and suitable for use. After the dry run, it was made ready for actual administration of the questionnaires. Upon approval, the researchers personally administered the questionnaires at a time agreed upon by the approving authority. Explicit instructions and motivations were given and explained aside from the instructions specified in the questionnaire for clarity.

The instrument consisted of three (3) parts. Part I is about the demographic profile of the respondents in terms of sex, highest educational attainment, years in teaching, designation and number of seminars attended related to ICT for the past five (5) years. Part II and III of the questionnaire addresses about the extent of the use of ICT integration into teaching and learning mathematics and the challenges encountered by the teacher on ICT - based teaching and learning in mathematics education respectively. There were fifteen (15) items on those part and rated based on the four-point Likert scale equivalence. It was provided by the following description: Option four (4) with a scale range from 3.254 .00 with a verbal interpretation of Very Great Extent or Strongly Agree; Option three (3) with a scale range of 2.50 - 3.24 with a verbal interpretation of Great Extent or Agree; Option two (2) with a scale range $1.75-2.49$ with a verbal interpretation of Little Extent or Disagree; and Option one (1) with a scale of $1.00-1.74$ with a verbal interpretation of No extent at all or Strongly Disagree.

Likewise, the researchers conducted a follow-up interview and FGD for the selected secondary school mathematics teachers. All schools were represented evenly for the follow up FGD. The weighted mean, frequency distribution, percentage, mean, standard deviation, and T-test were the statistical tools used to analyse the data gathered.

\section{Results and Discussion}

\section{Demographic profile of the respondents}

Table 1

Profile of the Respondents in Terms of Sex

\begin{tabular}{ccc}
\hline Sex & Frequency & Percentage \\
\hline Male & 31 & 40.26 \\
Female & 46 & 59.74 \\
\hline Total & 77 & 100 \\
\hline
\end{tabular}

Table 1 presents the distribution of respondents in terms of sex. Thirty one (31) or 40.26 percent are male and 46 or 59.74 percent are female. There was a total of seventyseven respondents in the study. The results yielded that most of the respondents were female. 
Table 2

Profile of the Respondents in Terms of Their Educational Attainment

Highest Educational Attainment

\begin{tabular}{ccc}
\hline Bachelor's Degree & 63 & 81.82 \\
Master's Degree & 14 & 18.18 \\
\hline Total & 77 & 100 \\
\hline
\end{tabular}

Distribution of the respondents in terms of their educational attainment is shown in Table 2 above. There are 63 or 81.82 percent bachelor's degree holder. Fourteen (14) or 18.18 percent are Master's degree holder. The results show that most of the respondents are Bachelor's degree holder.

Table 3

Profile of the Respondents in Terms of Years in the Service

\begin{tabular}{ccc}
\hline Years in the Service & Frequency & Percentage \\
\hline 15 and below & 57 & 74.03 \\
16 and above & 20 & 25.97 \\
\hline TOTAL & 77 & 100 \\
\hline
\end{tabular}

Table 3 shows the distribution of the respondents in terms of years in service. Fiftyseven (57) or 74.03 percent are from 15 years and below. Meanwhile, the remaining 25.97 percent with a frequency of 20 respondents are from 16 years and above in the service. As the results show, majority of the respondents are in the service for 15 years and less.

Table 4

Profile of the Respondents in Terms of Their Designation

\begin{tabular}{ccc}
\hline Designation & Frequency & Percentage \\
\hline Teacher & 72 & 93.51 \\
Master Teacher & 5 & 6.49 \\
\hline Total & 77 & 100 \\
\hline
\end{tabular}

Table 4 shows the distribution of the respondents in terms of their designation. Seventy-two (72) or 93.51 percent are Teachers I-III. Five or 6.49 percent are Master Teachers I-II. The results manifested that majority of the respondents are Teachers I-III. 
Table 5

Profile of the Respondents in Terms of Number of ICT - related seminar for the past 5 years

Number of ICT - Related Seminars Attended
Interpretation

Frequency

Percentage

\begin{tabular}{ccccc}
\hline $\begin{array}{c}5 \text { below } \\
6-10\end{array}$ & Not Active & 76 & 98.70 \\
& & Active & 1 & 1.30 \\
\hline & TOTAL & & 77 & 100 \\
\hline
\end{tabular}

Table 5 shows the distribution of the respondents in terms of the number of ICTrelated seminars attended for the past 5 years. Seventy-six (76) or 98.70 percent had attended 5 seminars and below which is verbally interpreted as not active. One or 1.30 percent had participated six to 10 seminars referred to as active. The result yielded that most of the respondents do not have enough training or seminars attended related to ICT integration in teaching mathematics.

As stated in Table 3, most of the respondents are in the service for 15 years and below. This can be the possible reason why in terms of the number of ICT-related seminars, majority or 76 respondents are not active since they only got to attend five and below.

The result is alarming since the $21^{\text {st }}$ Century education requires more touch of technological advancement in the classroom, with ICT integration in particular. The knowledge of the teachers in applying such in every lesson delivered to the students can be acquired from trainings. During the interview conducted, one teacher responded that she just had one opportunity to be part of mathematics-related ICT integration training. She can barely recall how thankful she was with an expectation that she would be having another chance to attend such kind. However, the same opportunity did not knock again. With this, she just inquires to other teachers whom she believes are more knowledgeable when it comes to various matters relative to ICT integration in mathematics. She also added that Learning Action Cell (LAC) is also of a great help to her since during each session teachers who have attended the seminars and trainings have the chance to cascade what they acquired. LAC Session is somewhat similar to a department meeting wherein the teachers were just sharing their knowledge and ideas from the previous trainings and seminars attended.

On the other hand, that one respondent who was able to attend at least 6 to 10 trainings is one of the ICT coordinators who happened to be a mathematics teacher as well. With this, he has more opportunity to participate in various trainings of ICT as far as mathematics teaching is concerned.

\section{Extent of the use of ICT integration in teaching and learning mathematics}

Table 6 shows the extent of the use of ICT integration into teaching and learning mathematics. The result of the survey yielded that the indicator "I use computers in writing lesson plans in Mathematics" got the highest weighted mean of 3.87 and has a verbal interpretation of very great extent. Daily lesson logs can be made easier through computers since its template is already provided by the Department of Education. The teachers just have to fill the necessary information for each part. 
Table 6

Extent of the use of ICT integration in teaching and learning mathematics

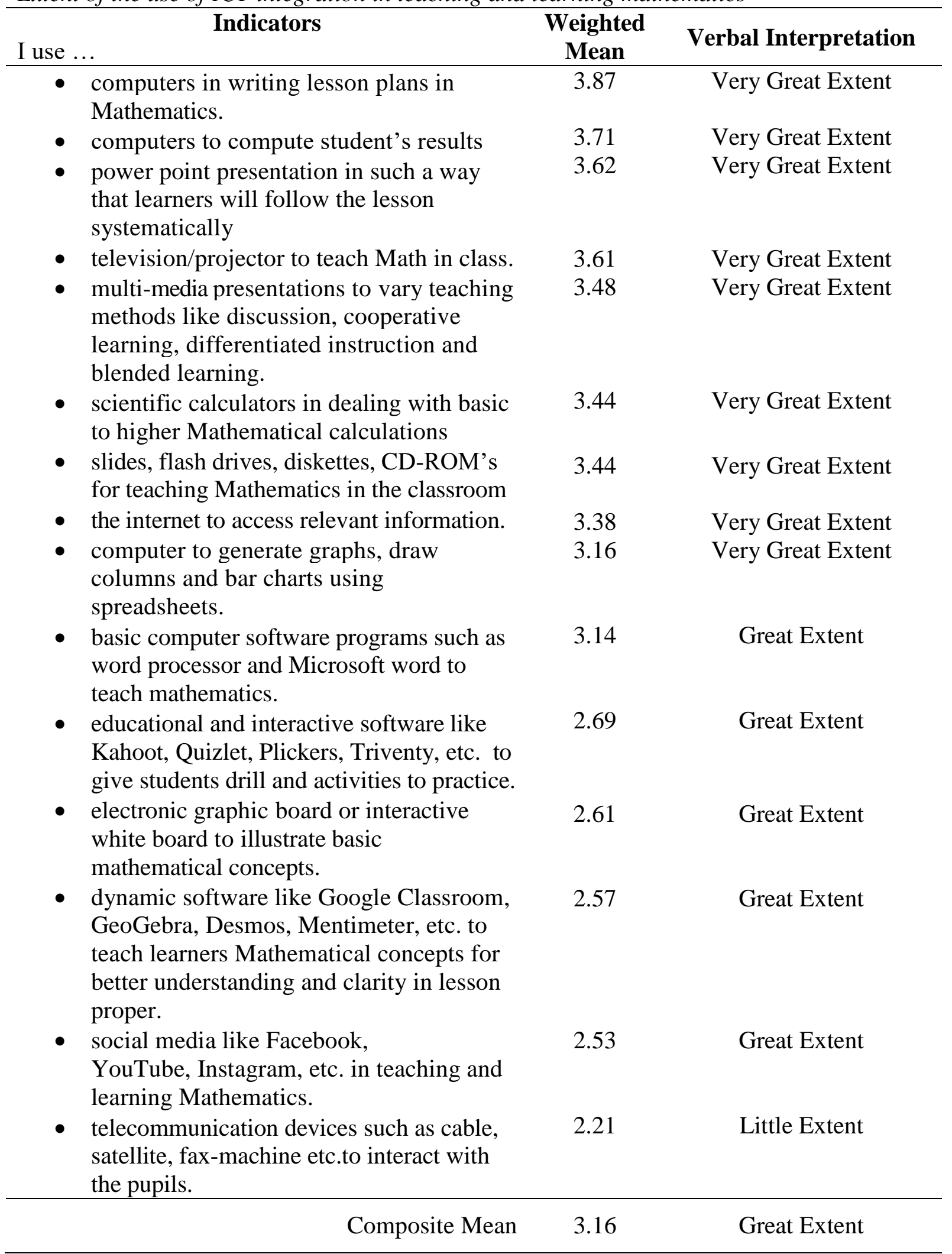

$\begin{aligned} \text { Legend: } 1-1.74 \text { No extent at All } & 1.75-2.49 \text { Little Extent } \\ 2.50-3.24 \text { Great Extent } & 3.25-4.00 \text { Very Great Extent }\end{aligned}$


"Even if making daily lesson logs are one of the difficult things we have to prepare before seeing our students, the department still finds ways to make our lives easier in coming up with one", one of the respondents shared during the FGD. The other respondent added that there are websites by which we can download available lesson logs and other materials for our lesson for the specific day or week. "All we need is internet connection and modify those that we downloaded according to the needs of our students", one more respondent delivered. The indicator, "I use computers to compute students' result" which has a weighted mean of 3.71 has a verbal interpretation of very great extent. The so-called E-Class Record or Electronic Class Record is also provided to teachers. Here, the teachers just have to input the scores of the students and then the final result will be yielded once every column has a complete entry. It was a great help for the teachers to make their computation easier and with lesser mistakes.

On the other hand, it was found out that when it comes to the use of other telecommunication devices such as cable, satellite, fax-machine etc. to interact with the pupils the teachers, the indicator only got a weighted mean of 2.21 which is verbally interpreted as little extent. As revealed in the FGD, lack of budget to allocate in purchasing cables or internet connections. Instead of putting internet, or cables, satellites, the budget is allocated for the maintenance of school, cleanliness and teacher/student developmental fund.

To sum up, the respondents utilized ICT in teaching and learning mathematics with a great extent as supported by the composite mean of 3.16. With this, it can be inferred that teachers really address the needs of our $21^{\text {st }}$ Century learners. It is never told that the traditional way of teaching has to be totally eliminated but based on the results, the teacherrespondents adjust to what is required by the K-12 curriculum.

The researchers were also able to record the response by one of the teachers. He mentioned that there was a time when he entered the room with his chalk and book only, and he observed that students did not have that interest to look at the board which may imply that they were not listening since it was a mathematics class. As he continued, he then shared that the next time he entered the room with the power point presentation (PPt) together with his chalk and board, students seem to be listening well, a sign of interest to learn.

The findings of the study are similar to the study of Ghavifekr and Rosdy (2015) which presented the degree of ICT integration of teachers into teaching and learning process is high. All the teacher-respondents were able to use computer as a tool for demonstration working with presentations, they have made themselves such as PPt. On the other hand, the results are contrary to the study of Bosah (2015), which revealed that there were no ICT devices available for teaching mathematics in schools thus, the teachers do not make use ICT devices in teaching mathematics in demonstration primary schools in Anambra State.

\section{Difference between the extent of teachers' integration of ICT-based teaching and learning in mathematics and the respondents' profile}

Table 7 shows the significant differences between the extent of teachers' integration of ICT-based teaching and learning in mathematics and the respondents' profile. From the variable presented, sex, education, designation and seminars attended have a p-value of $0.536,0.645,0.105$, and 0.170 respectively. Since, $p>0.05$, the null hypothesis was failed to reject, which means there is no significant differences between the extent of the use of ICT 
and the profile variables in terms of sex, education, designation and seminars attended. Thus, the data provide insufficient evidence to conclude that the extent of the use of ICT integration in teaching and learning mathematics is remarkable in those profile variables.

On the other hand, the results also show that the use of ICT integration of teachers whose years in teaching is 15 and below $(\mathrm{M}=3.27, \mathrm{SD}=0.50)$ is higher than the use of ICT of teachers whose years in teaching is 16 and above $(\mathrm{M}=2.88, \mathrm{SD}=0.44)$ and has a $\mathrm{p}$-value of 0.002. Since, $p<0.05$, the null hypothesis is rejected. This means that the means of the two groups are significantly different from each other. Thus, the data give sufficient evidence to conclude that the teachers whose years in teaching is below 15 integrate ICT-based teaching and learning mathematics higher than the teachers whose years in teaching is above 16. It can be inferred that seasoned teachers need to be updated in ICT-based teaching and learning mathematics and should be given more opportunities to attend seminars and trainings about ICT integration into mathematics.

Table 7

Significant Differences Between the Extent of Teachers' Integration of ICT-based Teaching and Learning in Mathematics and the Respondents' Profile

\begin{tabular}{|c|c|c|c|c|c|}
\hline Variables & Mean & $\begin{array}{l}\text { Standard } \\
\text { Deviation }\end{array}$ & $p$ - value & Decision & Interpretation \\
\hline \multicolumn{6}{|l|}{ Sex } \\
\hline Male & 3.21 & 0.47 & 0.536 & Failed to & \multirow{2}{*}{ Not Significant } \\
\hline Female & 3.13 & 0.54 & & Reject Ho & \\
\hline \multicolumn{6}{|l|}{ Education } \\
\hline Bachelor's & 3.15 & 0.53 & 0.645 & Failed to & \multirow{2}{*}{ Not Significant } \\
\hline Degree & 3.22 & 0.46 & & Reject Ho & \\
\hline \multicolumn{6}{|l|}{ Master's Degree } \\
\hline Years in Teaching & & & & & \multirow{3}{*}{ Significant } \\
\hline 15 and below & 3.27 & 0.50 & 0.002 & Reject Ho & \\
\hline 16 and above & 2.88 & 0.44 & & & \\
\hline \multicolumn{6}{|l|}{ Designation } \\
\hline Teacher & 3.18 & 0.52 & 0.105 & Failed to & \multirow{2}{*}{ Not Significant } \\
\hline Master Teacher & 2.87 & 0.39 & & Reject Ho & \\
\hline \multicolumn{5}{|l|}{ Seminars } & \multirow{3}{*}{ Not Significant } \\
\hline Not active & 3.15 & 0.51 & 0.170 & Failed to & \\
\hline Active & 3.87 & --- & & Reject Ho & \\
\hline
\end{tabular}

Legend: $p \leq 0.05$ Significant

$p>0.05$ Not Significant

The findings were opposed to the study conducted by Ghavifekr (2015) which presented that there is no significant difference between sex and extent of use of ICT. However, in the extent of use of ICT and years in service it was found to be significant.

\section{Challenges encountered by teacher on ICT-based teaching and learning in mathematics education}

Table 8 shows the challenges encountered by teacher on ICT-based teaching and learning in mathematics education. The result manifested that respondents all strongly agreed on the three indicators: "Shortage of basic infrastructure such as classrooms and Internet connectivity"; "Limited number and variety of subject-specific educational software available 
in schools"; and "Teachers' lack of confidence with the use of ICT in teaching-learning process", with a weighted mean of 3.47, 3.39 and 3.36 respectively. On the other hand, the respondents agreed to the remaining indicators and the item that has the lowest weighted mean is "Lack of teacher's knowledge on how to integrate ICT into pedagogical practice".

In the interview and FGD, respondents highlighted that lack of funding from the school as a contributing factor to insufficient resources. As stated, the only budget allocated to schools is for learner support material. The FGD also revealed that the absence or the slow internet connection is an obstacle to the utilization of the supposed available resources in various reliable websites. Also, as disclosed during the FGD, lack of training and seminars related to ICT integration in Mathematics teaching is one of the complaints of the teachers since they really believe that with these, they can gain learning which they can transfer to the teaching process. This result is also supported by the data garnered from the survey questionnaire.

In general, the teacher-respondents agreed on the different challenges encountered by the teacher on ICT based teaching and learning mathematics listed on the table. This was substantiated in the composite mean of 2.84. With this, it can be inferred that even if there is a call for the ICT integration in teaching mathematics and even to other subjects, the teacherrespondents are not ready enough in the full materialization of the integration of ICT in mathematics teaching and learning. Teachers still need to be trained more and the school has to have the necessary materials.

Table 8

Challenges Encountered by Teacher on ICT-based Teaching and Learning in Mathematics Education

\begin{tabular}{lcc}
\multicolumn{1}{c}{ Indicators } & $\begin{array}{c}\text { Weighted } \\
\text { Mean }\end{array}$ & $\begin{array}{c}\text { Verbal } \\
\text { Interpretation }\end{array}$ \\
\hline - $\begin{array}{l}\text { Shortage of basic infrastructure such as ICT } \\
\text { classrooms and Internet connectivity }\end{array}$ & 3.47 & Strongly Agree \\
- $\quad \begin{array}{l}\text { Limited number and variety of subject-specific } \\
\text { educational software available in schools }\end{array}$ & 3.39 & Strongly Agree \\
- $\quad \begin{array}{l}\text { Teachers' lack of confidence with the use of ICT } \\
\text { in teaching-learning process }\end{array}$ & 3.36 & Strongly Agree \\
- $\begin{array}{l}\text { Inadequate ICT equipment and resources like } \\
\text { computers, laptops, projectors, whiteboards etc., } \\
\text { available for students } \\
\text { Difficulties in scheduling enough computer time } \\
\text { for classes as a problem in the use of ICT in } \\
\text { teaching-learning }\end{array}$ & 3.18 & Agree \\
\end{tabular}




\begin{tabular}{|c|c|c|}
\hline Indicators & $\begin{array}{l}\text { Weighted } \\
\text { Mean }\end{array}$ & $\begin{array}{c}\text { Verbal } \\
\text { Interpretation }\end{array}$ \\
\hline $\begin{array}{l}\text { - Scarcity of time needed to locate internet } \\
\text { information, prepare lessons, explore and practice } \\
\text { using the ICT }\end{array}$ & 3.13 & Agree \\
\hline $\begin{array}{l}\text { Lack of sufficient trainings for teachers to develop } \\
\text { appropriate skills, knowledge, and attitudes } \\
\text { regarding the effective use of ICT to support } \\
\text { learning }\end{array}$ & 2.99 & Agree \\
\hline $\begin{array}{l}\text { Absence of specific curricular standards and } \\
\text { guidelines for integrating computers into the } \\
\text { subject areas }\end{array}$ & 2.97 & Agree \\
\hline $\begin{array}{l}\text { - Lack of technical support to encourage the use of } \\
\text { ICT from administration side }\end{array}$ & 2.91 & Agree \\
\hline $\begin{array}{l}\text { Lack of local school policy that will mandate } \\
\text { teachers to use ICT }\end{array}$ & 2.65 & Agree \\
\hline $\begin{array}{l}\text { - Teachers' attitudes toward ICT integration in } \\
\text { instructional settings }\end{array}$ & 2.60 & Agree \\
\hline $\begin{array}{l}\text { Lack of both technical and pedagogical } \\
\text { knowledge and skills of the teacher to use } \\
\text { available ICTs in the classroom }\end{array}$ & 2.53 & Agree \\
\hline $\begin{array}{l}\text { - Lack of teachers' acceptance and adoption of ICT } \\
\text { in the classroom }\end{array}$ & 2.49 & Disagree \\
\hline $\begin{array}{l}\text { - Society, school and colleagues' negative views } \\
\text { about ICT integration in class }\end{array}$ & 2.48 & Disagree \\
\hline $\begin{array}{l}\text { - Lack of teacher's knowledge on how to integrate } \\
\text { ICT into pedagogical practice }\end{array}$ & 2.38 & Disagree \\
\hline Composite Mean & 2.84 & Agree \\
\hline
\end{tabular}

$\begin{array}{lll}\text { Legend: } & 1-1.74 \text { Strongly Disagree } & 1.75-2.49 \text { Disagree } \\ 2.50-3.24 \text { Agree } & 3.25-4.00 \text { Strongly Agree }\end{array}$

As regards with the results, it seems that the teachers are challenged to teach the subject because of lack of resources like internet connection and some educational software. The teachers also lack confidence for some reason that they feel that in this $21^{\text {st }}$ Century education they are left behind. They also lack knowledge on integrating ICT into pedagogical practice and it is shown in the number of seminars attended for the last five years.

The findings of the study is similar to the study conducted by Ghavifekr and Rosdy (2015) which found that most teachers think ICT integration is effective, but ICT tools provided in school are not enough nor in good condition; training and professional development are not adequately provided for teachers; technical supports are somehow provided but can be improved from time to time; and not very good condition of computer lab in school with well-functioning tools and facilities. 
According to Jones (2004) much of the research proposes that confidence is a major barrier to the uptake of ICT by teachers in the classroom. Moreover, Balanskat, et. al (2006) also found that teacher's limited knowledge on ICT makes them feel anxious about using ICT in the classroom. Lack of knowledge makes a teacher less competent that would lead to lack of confidence (Bordios, 2016).

\section{Conclusion}

Based on the findings of the study, majority of them were female, bachelors graduate, from teacher I to III, 15 years below in the service and not active in the ICT-related seminars attended. Most of the respondents use technology in writing lesson plans, compute students result and power point presentation in teaching the lesson. However, due to the lack of resources and little fund from the MOOE, the respondents least use the telecommunication devices such as cable, satellite, fax-machine etc. to interact with the pupils or sometimes no use at all. There is a significant difference between the extent of the use of ICT in teaching and learning mathematics and years in teaching. Meanwhile, the remaining profile variables such as sex, education, designation and seminars have no significant difference to the extent of the use of ICT in teaching and learning mathematics. It seems that the teachers are challenged to teach the subject by lacking of resources like internet connection and some educational software. The teachers also lack confidence for some reason that they feel that in this $21^{\text {st }}$ Century education they feel left behind. They also lack of knowledge on integrating ICT into pedagogical practice and it is shown in the number of seminars attended for the last five years.

\section{Acknowledgements}

The researchers would like to extend their deepest gratitude to the following individuals for making this research possible. Dr. Emil A. Alcantara, Ph.D., for his words of wisdom for the improvement of the study, patience in giving important advices, highly competent remarks and invaluable suggestions that made this study successful. Dr. Ernesto Mandigma, for his detailed and constructive comments and suggestions for the enrichment of the study. Edna Faura - Agustin, Schools Division Superintendent, for granting the permission to gather data from the Public Secondary Schools in the Division of Tanauan City. Dr. Bryan Manalo, Dr. Charity Aldover, Mr. Don S. Avelino, for validating the questionnaires. Principals/Officer-in-Charge of all the Public Secondary Schools in the Division of Tanauan City for assisting us to conduct and administer the questionnaires. Mrs. Rodelyn O. Castañas, for helping us to interpret and analyse the qualitative part of the study. Co-teachers and colleagues in the profession for the sweet advices and support. Researcher's family and loved ones, for the love, moral support, encouragement and financial support, and above all, to the ALMIGHTY GOD, for his never-ending guidance in conducting and accomplishing this study, despite all difficulties. 


\section{References}

Balanskat, A., Blamire, R., \& Kefala, S. (2006). The ICT impact report: A review of studies of ICT impact on schools in Europe. European Communities.

Baya'a, N., \& Daher, W. (2013). Mathematics teachers' readiness to integrate ICT in the classroom: The case of elementary and middle school Arab teachers in Israel. International Journal of Emerging Technologies in Learning, 8(1). Retrieved from: http://dx.doi.org/10.3991/ijet.v8i1.2386

Bonifacio, A. L. (2013). Developing Information Communication Technology (ICT) curriculum standards for K-12 schools in the Philippines. In The Sixth Conference of MIT's Learning International Networks Consortium (LINC), MIT, Cambridge, Massachusetts, USA.

Bordios, E. (2016). Determinant factors in the integration of information and communication technologies in teaching. Univ. of Min. Intl. Mult. Res. Jour. 1(2). Retrieved from: https://www.researchgate.net/publication/315574177_Determinant_factors_in_the_int egration_of_information_and_communication_technologies_in_teaching

Bosah, I., Obumneke-Okeke, I., \& Anyachebelu, F. (2015). Extent of integration of I.C.T. in the teaching of Mathematics in demonstration primary schools in Anambra State. Proceeding in $2^{\text {nd }}$ National Conference of Association of Childhood Educators Nigeria at Nnamdi Azikiwe University, Awka. Retrieved from: https://www.researchgate.net/publication/309642404_EXTENT_OF_INTEGRATIO N_OF_ICT_IN_THE_TEACHING_OF_MATHEMATICS_IN_DEMONSTRATION _PRIMARY_SCHOOLS_IN_ANAMBRA_STATE

Comi, S. L., Argentin, G., Gui, M., Origo, F., \& Pagani, L. (2017). Is it the way they use it? Teachers, ICT and student achievement. Economics of Education Review, 56, 24-39.

Delen, E., \& Bulut, O. (2011). The Relationship between Students' Exposure to Technology and Their Achievement in Science and Math. Turkish Online Journal of Educational Technology-TOJET, 10(3), 311-317.

Eickelmann, B., Gerick, J., \& Koop, C. (2017). ICT use in mathematics lessons and the mathematics achievement of secondary school students by international comparison: Which role do school level factors play?. Education and Information Technologies, 22(4), 1527-1551.

Ghavifekr, S., Kunjappan, T., Ramasamy, L., \& Anthony, A. (2016). Teaching and Learning with ICT Tools: Issues and Challenges from Teachers' Perceptions. Malaysian Online Journal of Educational Technology, 4(2), 38-57.

Ghavifekr, S., Razak, A. Z. A., Ghani, M. F. A., Ran, N. Y., Meixi, Y., \& Tengyue, Z. (2014). ICT integration in education: Incorporation for teaching \& learning improvement. Malaysian Online Journal of Educational Technology, 2(2), 24-45.

Ghavifekr, S., \& Rosdy, W. A. W. (2015). Teaching and learning with technology: Effectiveness of ICT integration in schools. International Journal of Research in Education and Science, 1(2), 175-191.

Jones, A. (2004). A review of the research literature on barriers to the uptake of ICT by teachers.

Kaleli-Yilmaz, G. (2015). The views of mathematics teachers on the factors affecting the integration of technology in mathematics courses. Australian Journal of Teacher Education, 40(8). Retrieved from: http://dx.doi.org/10.14221/ajte.2015v40n8.8 
Manaligod, H. J. T., \& García, X. L. (2012). Integration of information \& communication technology in public secondary schools in metro-Manila, Philippines (Doctoral dissertation, Doctoral dissertation). Retrieved from https://minerva. usc. es/xmlui/bitstream/handle/10347/6112/rep_250. pdf).

Mishra, P., \& Koehler, M. J. (2006). Technological pedagogical content knowledge: A framework for teacher knowledge. Teachers college record, 108(6), 1017-1054.

National Council for Teachers of Mathematics. (2000). Principles and standards for school mathematics. Reston, VA: Author.

Ngeze, L. (2017). ICT integration in teaching and learning in secondary schools in Tanzania: Readiness and way forward. International Journal of Information and Education Technology, 7(6). Retrieved from: http://www.ijiet.org/vol7/905-JR225.pdf

Salehi, H., \& Salehi, Z. (2012). Challenges for using ICT in education: Teachers' insights. International Journal of e-Education, e-Business, e-Management and e-Learning, 2(1). Retrieved from: http://ijeeee.org/Papers/078-Z00061F10037.pdf 